\title{
Designing a minimal synthetase
}

\author{
Radoslaw Piast, Rafał Wieczorek, Aleksandra Misicka
}

Warsaw University, Poland

https://doi.org/10.17952/35EPS.2018.136

\begin{abstract}
Minimal enzymes are enzymatic units reduced to the bare essentials with a preservation of their basic functional catalytic activity. The most famous example is Ser-His dipeptide - a minimal hydrolase. Such minimal enzymes are thought to be a missing link between prebiotic chemistry and the first organisms in the early Earth environment and hold potential for industrial use in place of enzymes in the future. As far as Ser-His dipeptide can be used to condensate substrates, this reaction is unfavorable in a water environment. In aqueous conditions direction of the reaction will be shifted from polymerization to hydrolysis. There is, however, another type of enzymes that deal with this problem by coupling unfavorable reactions with promoted ones. Synthetases are driven by hydrolysis of the pyrophosphate bond which they couple with the reaction of synthesis.
\end{abstract}

\section{Introduction}

The most widespread origin of life hypothesis is "RNA world". Although RNA molecules possess many properties crucial for life like the ability to store information, ability to evolve and catalysis their creation in the prebiotic environment remains uncertain [1]. Peptides and amino acids, on the other hand, have been proven to be produced in a variety of prebiotic reactions $[2,3,4,5,6]$ which makes them probably first life-related organic polymers on Earth [7].

"Irreducible complexity" is partially obsoleted term that nowadays regards codependency between proteins and nucleic acids. In great simplification proteins (polymerases) produce nucleic acids and nucleic acids (ribosomes) produce proteins. This dependency is being found in all life forms across the Tree of Life thus it must have evolved very early in the history of life [8].

We believe that peptides have been present in the process of replication of nucleic acids from the very beginning. Moreover, their (peptides) enzymatic activity could have allowed nucleic acids to emerge as information polymers[9].

In order to do so, these peptides would have to possess properties related to polymerases. Since nearly all the reactions in the "irreducible complexity" can be broken down into chains of phosphorylation a and phosphate residue substitution [10] (which reactions define enzymes from the class of synthetases) what we have started to seek is a minimal synthetase.

\section{Results and Discussion}

We have synthesized a number of designed peptides. Two of them expressed similar to expected properties. We have checked for desired activities in a variety of conditions. Observation worth of notice is that the reaction course is $\mathrm{pH}$ dependent. In alkaline $\mathrm{pH}$ peptide $\mathrm{C} 1$ catalyzes the hydrolysis of pyrophosphate (Fig. 1A).

Peptide $\mathrm{C} 1$ and peptide $\mathrm{C} 3$ in acidic conditions are able to activate themselves by phosphorylation and subsequently substitute phosphate residue with an amino acid from the environment(Fig. 1B). Presence of Leu-NH as a substituted amino acid suggests that activation takes place via carboxyl end.

Peptide $\mathrm{C} 1$ also possess the ability to dissolve and decompose pyrophosphate from calcium pyrophosphate crystals, a potential source of phosphates in the early Earth conditions thus possess chemolithotrophicabilities.

We achieved similar to desired catalytic properties. Following experiments will be conducted to better catalytic properties toward catalysis instead of autocatalysis and higher turnover speed. Minimal enzymes like the ones presented here could be a missing link between chemistry and biology and importantcatalytic power for the first nucleic acid replicons. Moreover, small peptidic catalysts could be used in the future as a cheaper and more stable substitute for enzymes in bioreactors and new forms of drugs. 


\section{Methods}

Design. In order to design minimal synthetases, we have investigated various enzymes involved in phosphate transfer chemistry (kinases, synthetases, polymerases). In all of these enzymes, the noticeable feature was a layer-like arrangement of crucial residues and substrates. Subsequently, we have transferred these properties onto smaller, peptidic units and performed a series of energy minimalizations in silico using ICM-Pro and Gromacs software. Peptides with best properties were synthesized using SPPS Fmoc strategy.

Activity assays. We were incubating peptides with $\mathrm{Mg}$ ions, pyrophosphate, $\mathrm{N}-\mathrm{Me}-\mathrm{Phe}-\mathrm{OH}$ and $\mathrm{H}-\mathrm{Leu}-\mathrm{NH}_{2}$. As a control, we have used mixtures with Ser-His dipeptide, without peptide and without peptide and $\mathrm{Mg}$ ions.

To measure the catalytic properties of designed peptides we have used two types of assays: indirect (measurement of pyrophosphate utilization) and direct (peptide bond formation via HPLC -TOF-MS)

We have monitored the reaction by measuring the concentration of phosphates in the reaction tubes via micro determination of phosphates [10] and in the end, we were checking for the presence of peptide derivatives. Three such derivatives could have been produced: $\mathrm{N}-\mathrm{Me}$-Phe-peptide, peptide-Leu- $\mathrm{NH}_{2}$, and $\mathrm{N}-\mathrm{Me}-\mathrm{Phe}-\mathrm{Leu}-\mathrm{NH}_{2}$.
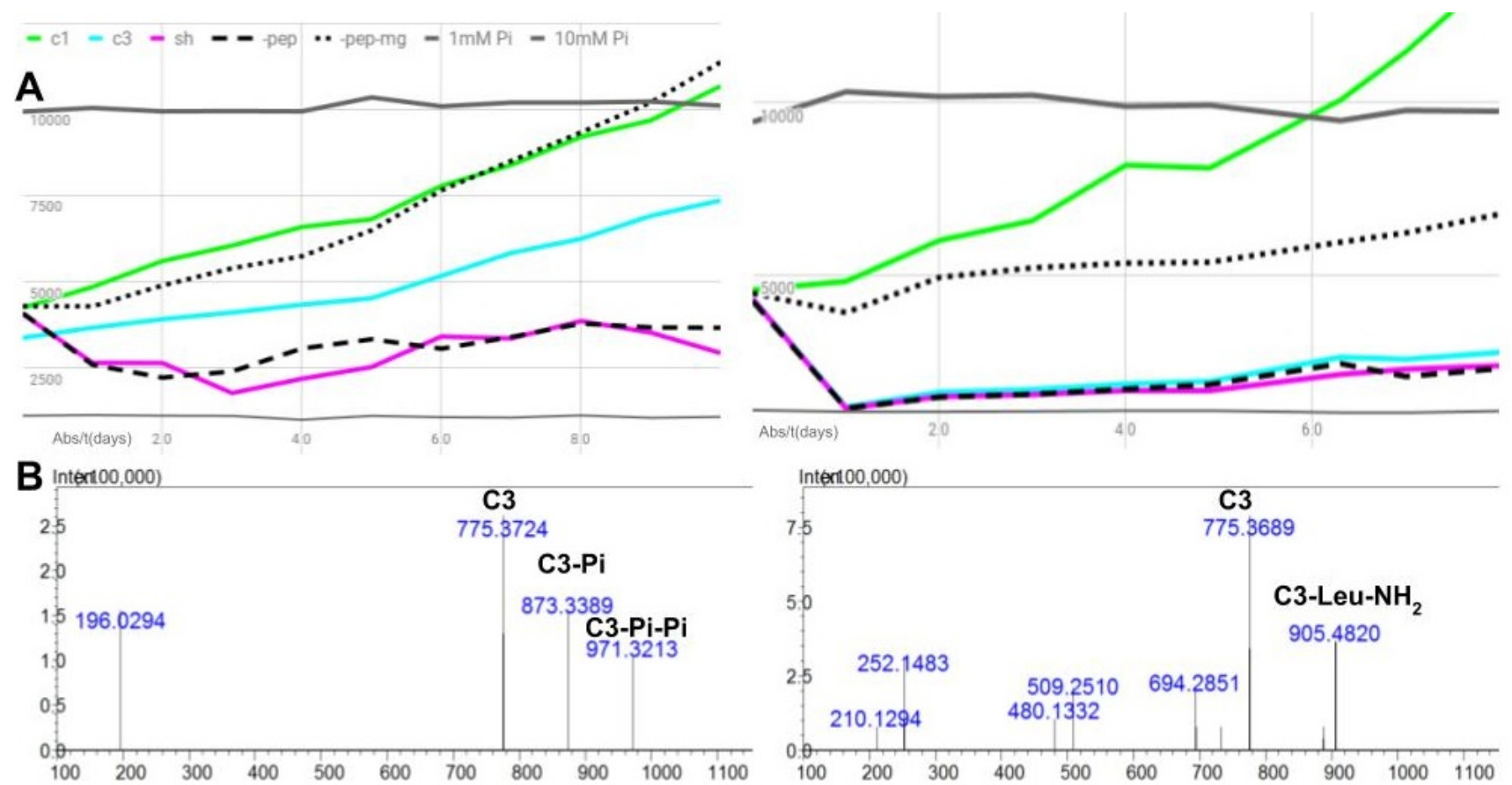

Figure 1: A: $p H$ dependency between two types of reactions: synthetase on the left at low $p H$ and pyrophosphate hydrolysis on the right at high $\mathrm{pH}$. Only peptides C1, C3 and Ser-His shown. Dotted lines are controls without peptide and without peptide and $\mathrm{Mg}$ ions, solid grey lines represent known concentrations of phosphoric acid. Absorbance shown as Ax10000 and time in days. B: Mass spectra of C3 peptide reaction with $\mathrm{Mg}$ ions, pyrophosphate, $\mathrm{N}-\mathrm{Me}-\mathrm{Phe}-\mathrm{OH}$ and $\mathrm{H}-\mathrm{Leu}-\mathrm{NH}_{2}$. Picks corresponding to phosphorylated peptide and leucinated peptide are present.

\section{Acknowledgments}

The project was carried out with the use of CePT infrastructure financed by the European Union - the European Regional Development Fund within the Operational Programme"Innovative economy" for 2007-13.

This work was also supported by an NCN grant 501-D112-66-0005680 


\section{References}

1. Muluye RA, Bian Y, Alemu PN. 2014. J Tradit Complement Med 4: 93-8

2. Xie C, Kokubun T, Houghton PJ, Simmonds MSJ. 2004. Phytotherapy Research 18: 497-500

3. Craik DJ, Swedberg JE, Mylne JS, Cemazar M. 2012. Expert Opin Drug Discov 7: 179-94

4. Weidmann J, Craik DJ. 2016. J Exp Bot 67: 4801-12

5. Pranting M, Loov C, Burman R, Goransson U, Andersson DI. 2010. J Antimicrob Chemother 65: 1964-71

6. Cao P, Yang Y, Uche FI, Hart SR, Li WW, Yuan C. 2018. Int J Mol Sci 19: 793

7. Rode, B.M. (1999). Peptides 20:773-786.

8. Orgel, L.E. (2000). Proc Natl Acad Sci USA 97:12503-12507.

9. Piast, R. W., \& Wieczorek, R. M. (2017). Astrobiology, 17(3), 277-285.

10. Chen, P. S., Toribara, T. T., \& Warner, H. (1956). Analytical Chemistry, 28(11), 1756-1758. 